Relations industrielles

Industrial Relations

\title{
Le coeur à l'ouvrage, par Gérard Lefebvre, Montréal, Les Éditions de l'Homme, 1982, 120 pp., ISBN 2-7619-0188-6.
}

\section{Dimitri Weiss}

Volume 38, numéro 1, 1983

URI : https://id.erudit.org/iderudit/029341ar

DOI : https://doi.org/10.7202/029341ar

Aller au sommaire du numéro

Éditeur(s)

Département des relations industrielles de l'Université Laval

ISSN

0034-379X (imprimé)

1703-8138 (numérique)

Découvrir la revue

Citer ce compte rendu

Weiss, D. (1983). Compte rendu de [Le coeur à l'ouvrage, par Gérard Lefebvre, Montréal, Les Éditions de l'Homme, 1982, 120 pp., ISBN 2-7619-0188-6.]

Relations industrielles / Industrial Relations, 38(1), 187-188.

https://doi.org/10.7202/029341ar

Tous droits réservés @ C Département des relations industrielles de l'Université Laval, 1983
Ce document est protégé par la loi sur le droit d'auteur. L’utilisation des services d'Érudit (y compris la reproduction) est assujettie à sa politique d'utilisation que vous pouvez consulter en ligne.

https://apropos.erudit.org/fr/usagers/politique-dutilisation/ 
structures of collective bargaining, the roles of the industrial parties, the operation of collective bargaining and the relative efficiences of the American and West European systems in terms of wage inflation, productivity and industrial conflict. For the most part his findings coincide with those of other authors in the book. He does point out at least two very important weaknesses in the U.S. System of Industrial Relations; namely, (1) labor movement has no coherent philosophy; (2) unions lack political power and the credibility within the American society. This reviewer would have preferred some discussion in this article of the impact of the changes in the international economics climate on the U.S. industrial relations. The recent developments in the international economic arena may also determine the nature of the direction of the U.S. industrial relations system in the future.

The reviewer agrees with the overall assessment of the U.S. industrial relations system by Stieber and Block that the changes described above "so far have not been of sufficient magnitude to threaten the viability of the U.S. system of industrial relations". However, the trend in the early 1980's do not augur well for the U.S. system of industrial relations given the government withdrawal from a vast array of economic activity pertaining to the employment relationship, the decline in unionization, the non-union option, etc.

Overall the articles in this book provide a fairly comprehensive picture of the U.S. industrial relations over the last three decades. For those interested in the U.S. Industrial Relations System, this volume is strongly recommended.

\section{Mahmood A. ZAIDI}

\section{University of Minnesota}

Le coeur à l'ouvrage par Gérard Lefebvre, Montréal, Les Éditions de l'Homme, 1982, 120 pp., ISBN 2-7619-0188-6.

On m'a souvent demandé si je connaissais un livre simple, écrit pour tout le monde, bref et pas cher, qui puisse introduire à ce qu'on pourrait, en gros, appeler une approche organisationnelle des relations industrielles. Ce livre, je viens de le lire: il est québécois, il est clair, bien écrit et prêt à être adopté -avec un égal bonheur, ce qui est rare- des deux côtés de l'Atlantique.

L'auteur, conseiller en gestion et médiateur dans les conflits d'entreprises, aborde dès l'entrée le problème de la qualité de la vie et de travail, "problème de fond" comme il le dit, qui appelle un changement de perspective supposant l'acceptation d'un concept différent d'organisation du travail. Cette face de la médaille, plus politique (au sens managérial du terme), qui tenait jusqu'à présent -ou jusqu'il n'y a pas longtemps- du pouvoir discrétionnaire du chef d'entreprise -se situant en dehors de l'interaction, conflictuelle et contractuelle, des acteurs du système de relations du travail, limitée à l'autre face: les conditions de travail- est lentement pénétrée par une forme de participation directe qui suppose, et requiert, une évolution intellectuelle commune des syndicats et du management. C'est ce que Lefebvre appelle «un second front».

Une deuxième partie est consacrée aux champs de la satisfaction au travail: rémunération, sécurité physique et santé, le travail posté, la sécurité d'emploi, un travail intéressant, des équipes de travail solidaires, des règles de régie, connues et justes, l'intégration de l'entreprise dans le milieu. La troisième, intitulée "design organisationnel", définit et explique les notions essentielles d'organisation du travail et d'approche systémique. La quatrième traite de l'intervention organisationnelle sous le jour de la qualité de vie et de travail, et présente notamment le développement organisationnel comme mode d'intervention fondé sur la collaboration. La cinquième, «la dure éprouve du changement», est suivie d'un examen de «trois obstacles à un changement»: la méfiance patronale/syndicale, le partage des bénéfices et le vieux mythe selon lequel la responsabilité ne se délègue pas. Ce qui amène l'auteur, dans la septième partie, à lancer, dans une «lettre 
ouverte à la génération de 36 », un appel à la responsabilisation. La dernière partie offre, sous le titre "Les influences», une bibliographie essentielle.

L'ouvrage se termine, comme il a commencé, sur la qualité de vie au travail, partie dans laquelle l'auteur nous of fre une gerbe de définitions personnelles de la QVT.

Ce livre, pertinent et complet dans sa brièveté, qui, en parlant de l'individuel, du groupe et du direct, n'oublie pas l'indirect et le collectif, rassemble dans une rédaction nette et personnelle -nourrie et illustrée par l'expérience-, les idées-clefs de ce qu'on appelle, mal ou bien, la dimension organisationnelle de l'entreprise. On ne pouvait en souhaiter de meilleurs prolégomènes, adressés au grand nombre. Et les lecteurs français découvriront -avec surprise ou ravissement-la similitude des situations existantes sous des cieux dont on s'est plu à nous décrire jusqu'à présent plutôt les distinctions. Des rapprochements ne manqueront pas d'être opérés. À moins que - et ce n'est pas là le moindre mérite de Gérald Lefebvre - les lecteurs hexagonaux aient tout simplement la conviction de lire un de leurs propres concitoyens.

\section{Dimitri WEISS}

\section{Université du Maine}

et Institut d'Administration des

Entreprises, Paris

\section{The Reshaping of the National Labor Rela- tions Board: National Labor Policy in} Transition 1937-1947, by James A. Gross, Albany: State University of New York Press, 1981, 381 pp., ISBN 0-87395-270-7

This is the second volume of a major study of the collective bargaining system that emerged in the United States during the New Deal era. In an earlier book the author, a professor of industrial relations at Cornell, described the circumstances leading to the passage of the Wagner Act in 1935 and the creation of the National Labor Relations Board. In this volume he draws upon NLRB files, Congressional records, newspapers, and extensive interviews with the principals to describe the first crucial decade of the NLRB's work. It is not a success story, for the author argues that the Board "was transformed from an expert administrative agency that played the major role in making of labor policy into a conservative, insecure, politically sensitive agency preoccupied with its survival." (4) This bold assertion transforms what might have been yet another dull exercise in administrative history into a provocative and stimulating read.

While the first volume chronicled the rise of the NLRB, this book details its "fall". The original members of the Board were idealists who vigorously enforced the Wagner Act and helped mightily to alter the balance of power between employers and workers. $\mathrm{He}$ gives them very high marks indeed for enforcing the Wagner Act with a vigor "unmatched in the history of administrative agencies." (23) As a result both trade unionism and the level of industrial conflict escalated in the United States. But then a political reaction set in. Although the Board won court decisions upholding its authority and rules, it began to receive a bad press. That was its own fault, he says, because some of its decisions appeared to tolerate violations of law and order by workers. Congressmen began to complain that the Board was, to quote one diatribe, a " "partisan, prejudiced, perfidious, persecuting, penalizing, putrid institution to browbeat, bulldoze, and bully the people." (51) Gross presents a damning indictment of the AFL for risking the demise of the Wagner Act in order to advance its own selfish and bitter struggle against the CIO.

Although the Roosevelt administration had given birth to the Wagner Act, it failed to come to the NLRB's defence. FDR was trying to keep in good graces with both wings of the labour movement. He appointed a respected mediator to the Board in an effort to improve its public image, but the new Board member promptly precipitated an internal power struggle that only weakened the Board's ability to withstand its critics. More important, 